\title{
PRECISION OF CALIBRATED RADIOCARBON AGES OF HISTORIC EARTHQUAKES IN THE DEAD SEA BASIN
}

\author{
Revital Ken-Tor ${ }^{1,2} \bullet$ Mordechai Stein $^{1} \bullet$ Yehouda Enzel $^{1} \bullet$ Amotz Agnon $^{1} \bullet$ Shmuel Marco ${ }^{2,3}$ \\ Jorg F W Negendank ${ }^{4}$
}

\begin{abstract}
The precise determination of the age of historical and geological events by radiocarbon dating is often hampered by the long intersection ranges of the measured data with the calibration curve. In this study we examine the possibility of narrowing the calibrated range of the ${ }^{14} \mathrm{C}$ ages of earthquake-disturbed sediments (seismites) from the Late Holocene lacustrine section in the Dead Sea Basin. The calibrated ranges of samples collected from seismites were refined by applying stratigraphic constraints and tuning the calibrated ranges to known historical earthquakes. Most of the earthquakes fall well within the $1 \sigma$ error envelope of the ${ }^{14} \mathrm{C}$ age. This refinement demonstrates that the lag period due to transport and deposition of vegetation debris is very short in this arid environment, probably not more than a few decades. This assessment of seismite ${ }^{14} \mathrm{C}$ ages attests to the validity of ${ }^{14} \mathrm{C}$ ages in Holocene sediments of the arid area of the Dead Sea. Furthermore, it demonstrates our ability to achieve highly precise (correct to within several decades) ${ }^{14} \mathrm{C}$ ages.
\end{abstract}

\section{INTRODUCTION}

Radiocarbon dating is one of the most widely applied dating methods for late Quaternary geology and archeology. The introduction of the accelerator mass spectrometry (AMS) technique improved the possibility of dating small samples and refined the analytical results. Nevertheless, the possibility of achieving highly precise ${ }^{14} \mathrm{C}$ dates is hampered by the need to transform the measured ${ }^{14} \mathrm{C}$ age to its calibrated date. The intersection of the ${ }^{14} \mathrm{C}$ age of the sample (within the $2 \sigma$ analytical error envelope) with the calibration curve, which accounts for the variations in ${ }^{14} \mathrm{C}$ content in the atmosphere (Suess 1965), typically yields a large range of calendar years. This may hamper the geological evaluation of instantaneous catastrophic events such as earthquakes or floods.

Recently, we have studied a late Holocene geological section from the Dead Sea Basin, which contains layers that were deformed by earthquakes (seismites). We established the chronology of this sequence by $25{ }^{14} \mathrm{C}$ measurements on organic debris collected along the section including samples from the seismites themselves. The organic debris, which are used to determine the seismites age, reached their depositional site prior to the formation of the seismite during the earthquake. Here we address several fundamental questions: How reliable are the ages to precisely determine the timing of earthquake? How long was the organic debris traveling in the drainage basin prior to its deposition? Moreover, how suitable for ${ }^{14} \mathrm{C}$ dating are the organic debris collected from the sediments of the arid area of the Dead Sea, where they can survive and be recycled for longer periods of time? A comparison between the ages of the debris from the seismites and reported historical earthquakes from the Dead Sea area (Ken-Tor et al. 2001) can help resolve these issues and assist in age determination of pre-historical sequences.

Here, we use the historical calendar dates of earthquakes to examine the potential for narrowing the $2 \sigma$ range of the ${ }^{14} \mathrm{C}$-calibrated ages, and to estimate the time lapsed between the ${ }^{14} \mathrm{C}$ age of the organic samples and the earthquake event that disturbed the units from which they were collected.

\footnotetext{
${ }^{1}$ Institute of Earth Sciences, The Hebrew University, Givat Ram, Jerusalem 91904, Israel

${ }^{2}$ Geological Survey of Israel, 30 Malkhei Israel St., Jerusalem 95501, Israel

${ }^{3}$ Department of Geophysics and Planetary Sciences, Tel Aviv University, Ramat Aviv, Tel Aviv 69978, Israel

${ }^{4}$ GeoForschungsZentrum Potsdam, Telegrafenberg, D-14473 Potsdam, Germany
}

(C) 2001 by the Arizona Board of Regents on behalf of the University of Arizona

Near East Chronology: Archaeology and Environment. RADIOCARBON, Vol 43, Nr 3, 2001, p 1371-1382

Proceedings of the 17th International ${ }^{14} \mathrm{C}$ Conference, edited by $\mathrm{H} J$ Bruins, I Carmi, and E Boaretto 


\section{Geological Background and Chronology}

The samples for ${ }^{14} \mathrm{C}$ analyses were collected from a sequence of Holocene deposits exposed along the shores of the Dead Sea, at the Ze'elim Terrace (Figure 1). The sequence consists of lacustrine sediments of laminated aragonite and detritus, and sandy beds representing shore and shallow, nearshore environments. The sequence contains several unconformities, representing episodes of lower lake levels and erosion (see Ken-Tor et al. 2001 for detailed description).

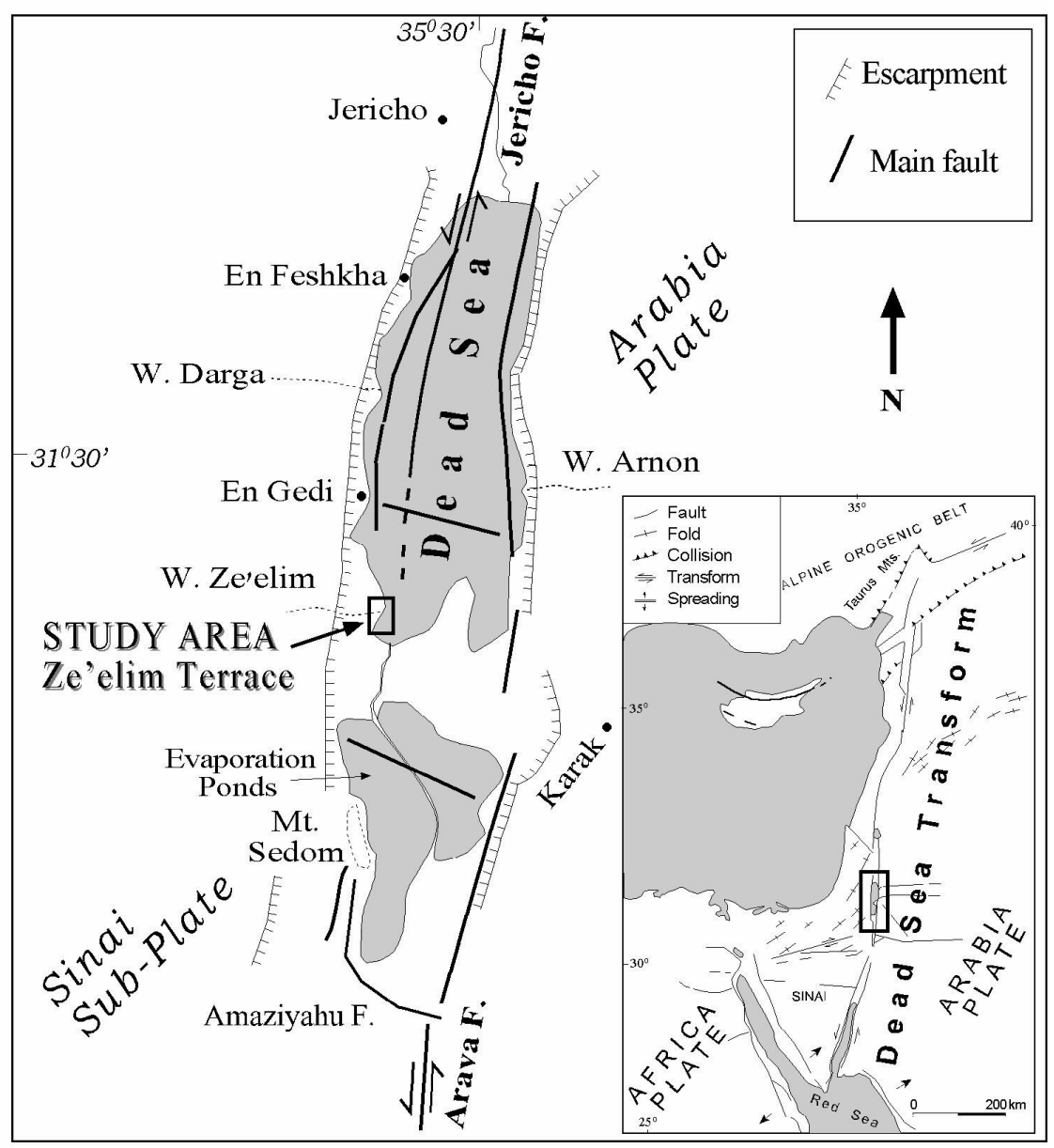

Figure 1 Location map of the Dead Sea area and general setting of the Dead Sea Transform (modified after Garfunkel et al. 1981). The study site is located at the Ze'elim Terrace at the western shore of the lake.

The Ze'elim section exposes beds that experienced soft-sediment deformation (Figure 2). These beds consist of mixtures of fine-grained dark clay and silt, with laminated, tabular fragments of aragonite (millimeters to a few centimeters long) and liquefied coarse sands. The beds are a few centimeters to a few tens of centimeters thick, with sharp and flat upper contacts with overlying undeformed beds. Below and above each of these beds, the sequence is laminated and undisturbed, with no preferred orientation or any other indicators of transported sediments. The lateral distribution of the deformed 
units is not uniform; several of them extend over a large distance and can be traced and correlated among exposures in different gullies and cross-facies changes; others have limited distribution.

The soft-sediment deformation structures in the Dead Sea Basin sediments are interpreted as seismites (Marco and Agnon 1995; Marco et al. 1996; Enzel et al. 2000; Ken-Tor et al. 2001). Seismites were observed in the Late Pleistocene Lisan Formation in association with syndepositional surface fault ruptures that support their seismogenic origin (Marco and Agnon 1995). Each deformed bed represents an originally flat-lying laminated unit that was fluidized, brecciated, and suspended during an earthquake, and then re-settled in its present structure at the water-sediment interface on the lake bottom (Marco et al. 1996).

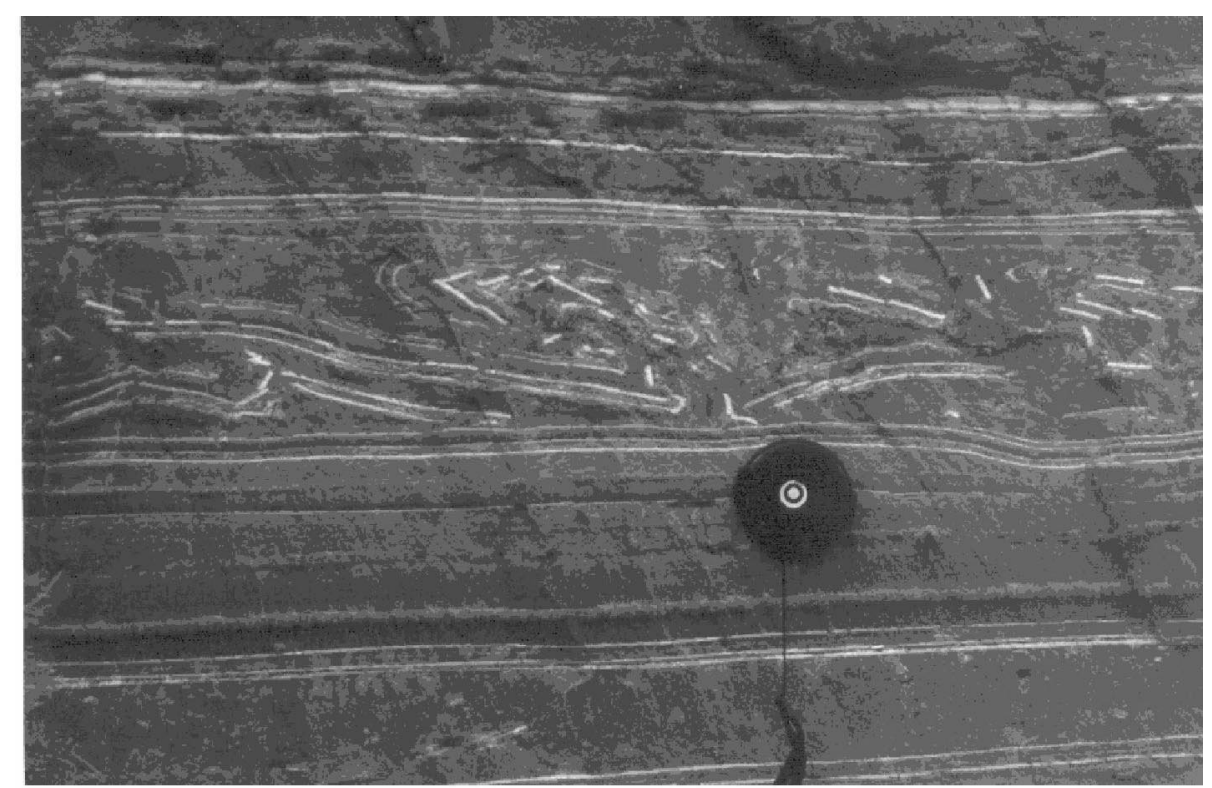

Figure 2 An example of a seismite in the Ze' elim sequence. The seismite is composed of aragonite fragments suspended in dark detritus. This seismite is correlated to the $31 \mathrm{BC}$ earthquake.

The chronology of the Ze'elim sequence was established by ${ }^{14} \mathrm{C}$ ages on vegetation debris (Ken-Tor et al. 2001). The detrital sediments from which the samples were recovered are rich in leaves, stalks, small branches, and seeds. These organic materials are debris of the vegetation growing in the Dead Sea area along streams and around fresh water springs. They were flushed into the lake by seasonal floods, and the lake's wave action could have transported them along the shores. Examination of the samples and the collection area excludes the possibility of contamination by the scarce vegetation growing on top of the sequence.

Table 1 lists 25 samples from 16 distinct stratigraphic horizons, their ${ }^{14} \mathrm{C}$ ages from the youngest to the oldest, the material dated, and their calibrated ${ }^{14} \mathrm{C}$ ages. The oldest part of the sequence was dated to $2230 \pm 30 \mathrm{BP}$; the top of the sequence was exposed as a result of a lake-level drop about 30 years ago. To test the reproducibility of results, multiple samples were collected from seven sedimentary horizons. This yielded overlapping error ranges, supporting the reliability of the dates. The precise ${ }^{14} \mathrm{C}$ ages are converted into calendar dates according to their intersection with the calibration curve of Stuiver et al. (1998). The intersection with the calibration curve can yield more than one 
choice for the calendar date of the sample; when added to the $2 \sigma$-envelope error, a range of calendar dates is deduced (Table 1, Figure 3).

The ages of six seismites in the sequence were constrained by ${ }^{14} \mathrm{C}$ dating of samples collected from the deformed layers (Table 2) (Ken-Tor et al. 2001). These ages were calibrated and the older intersect of the $2 \sigma$ range of each dated seismite unit was reduced by the younger intersect of the $2 \sigma$ range of the sample located stratigraphically below. This procedure allows us to resolve the calendar ages of units that yielded statistically indistinguishable analytical data (e.g. units 10 and 11, Figure 3b). The younger intersect of the calendar ranges of the seismite units is reduced by the historic dates of the earthquakes that were correlated to them since the calendar range of a sample collected from a seismite cannot significantly postdate the historic date of the earthquake. Moreover, the comparison with the historical dates allows the estimation of accuracy of the dating by ${ }^{14} \mathrm{C}$.

Table 1 AMS results of ${ }^{14} \mathrm{C}$ dating. Calibrated dates according to Stuiver et al. (1998). The samples are listed according to their stratigraphic height, top to bottom. In bold are samples collected from seismite units.

\begin{tabular}{|c|c|c|c|c|}
\hline $\begin{array}{l}\text { Sample } \\
\text { lab nr } \\
\text { (KIA-) }\end{array}$ & $\begin{array}{l}\text { Section } \\
\text { height }(\mathrm{cm})\end{array}$ & Material & $\begin{array}{l}{ }^{14} \mathrm{C} \mathrm{yr} \\
(\mathrm{BP})\end{array}$ & $\begin{array}{l}\text { Calibrated } 2 \sigma \\
\text { error range }\end{array}$ \\
\hline 8260 & $650^{\mathrm{a}}$ & Macro residue, alkali residue & $279 \pm 20$ & 1520-1670 AD \\
\hline 11651 & $620^{\mathrm{a}}$ & Wood, alkali residue & $93 \pm 36$ & 1670-1960 AD \\
\hline 8261 & $600^{\mathrm{a}}$ & Wood bark, alkali residue & $135 \pm 31$ & $1670-1960 \mathrm{AD}$ \\
\hline 8259 & $550^{\mathrm{a}}$ & Wood, alkali residue & $260 \pm 24$ & $1520-1800 \mathrm{AD}$ \\
\hline 3213 & $478.5-532.5$ & Wood, alkali residue & $600 \pm 40$ & $1290-1420 \mathrm{AD}$ \\
\hline $\begin{array}{l}3214 A \\
3215 \\
3216\end{array}$ & 519 & $\begin{array}{l}\text { Wood twig, alkali residue } \\
\text { Twigs, alkali residue } \\
\text { Diverse plant remains, seed, alkali residue }\end{array}$ & $\begin{array}{l}780 \pm 30 \\
660 \pm 30 \\
680 \pm 30\end{array}$ & $\begin{array}{l}1210-1290 \text { AD } \\
1280-1400 \text { AD } \\
1270-1400 \text { AD }\end{array}$ \\
\hline $\begin{array}{l}3217 \\
3218 \\
3219\end{array}$ & 469.5 & $\begin{array}{l}\text { Wood, alkali residue } \\
\text { Wood, alkali residue } \\
\text { Wood, alkali residue }\end{array}$ & $\begin{array}{l}690 \pm 30 \\
700 \pm 30 \\
760 \pm 30\end{array}$ & $\begin{array}{l}1270-1390 \mathrm{AD} \\
1260-1390 \mathrm{AD} \\
1220-1295 \mathrm{AD}\end{array}$ \\
\hline 8258 & $430^{\mathrm{a}}$ & Wood, alkali residue & $909 \pm 23$ & $1030-1210 \mathrm{AD}$ \\
\hline 3220 & 381.5 & Wood, alkali residue & $1630 \pm 40$ & $340-540 \mathrm{AD}$ \\
\hline $\begin{array}{l}3221 \\
3222\end{array}$ & 282.5 & $\begin{array}{l}\text { Stick, alkali residue } \\
\text { Stem, alkali residue }\end{array}$ & $\begin{array}{l}1760 \pm 40 \\
1800 \pm 50\end{array}$ & $\begin{array}{r}130-390 \mathrm{AD} \\
80-390 \mathrm{AD}\end{array}$ \\
\hline 3223 & 146 & Plant material, stem, alkali residue & $1950 \pm 60$ & 100 BC-230 AD \\
\hline $\begin{array}{l}3224 \\
3225\end{array}$ & 132.5 & $\begin{array}{l}\text { Wood, alkali residue } \\
\text { Wood, alkali residue }\end{array}$ & $\begin{array}{l}1940 \pm 40 \\
1930 \pm 50\end{array}$ & $\begin{array}{l}50 \mathrm{BC}-140 \mathrm{AD} \\
50 \mathrm{BC}-220 \mathrm{AD}\end{array}$ \\
\hline $\begin{array}{l}3227 \mathrm{~A} \\
3227 \mathrm{~B}\end{array}$ & 107 & $\begin{array}{l}\text { Diverse plant material, alkali residue } \\
\text { Diverse plant material, humic acid }\end{array}$ & $\begin{array}{l}1990 \pm 40 \\
1910 \pm 40\end{array}$ & $\begin{array}{l}50 \mathrm{BC}-80 \mathrm{AD} \\
0 \mathrm{AD}-230 \mathrm{AD}\end{array}$ \\
\hline 3228 & 73.5 & Diverse plant material, alkali residue & $2120 \pm 40$ & $360-40 \mathrm{BC}$ \\
\hline $\begin{array}{l}3232 \\
3233\end{array}$ & 51 & $\begin{array}{l}\text { Root or twig, stem, alkali residue } \\
\text { Wood, alkali residue }\end{array}$ & $\begin{array}{l}2050 \pm 40 \\
2120 \pm 30\end{array}$ & $\begin{array}{r}170 \mathrm{BC}-50 \mathrm{AD} \\
350-40 \mathrm{BC}\end{array}$ \\
\hline $\begin{array}{l}3234 \\
3235\end{array}$ & 14.5 & $\begin{array}{l}\text { Stem and root, alkali residue }{ }^{\mathrm{b}} \\
\text { Stem, alkali residue }\end{array}$ & $\begin{array}{l}2230 \pm 30 \\
2190 \pm 30\end{array}$ & $\begin{array}{l}390-200 \mathrm{BC} \\
380-160 \mathrm{BC}\end{array}$ \\
\hline
\end{tabular}

a Samples collected from the southern section (see composite section, Figure 3 in Ken-Tor et al. 2001)

${ }^{b}$ Root debris (not in-situ root) 


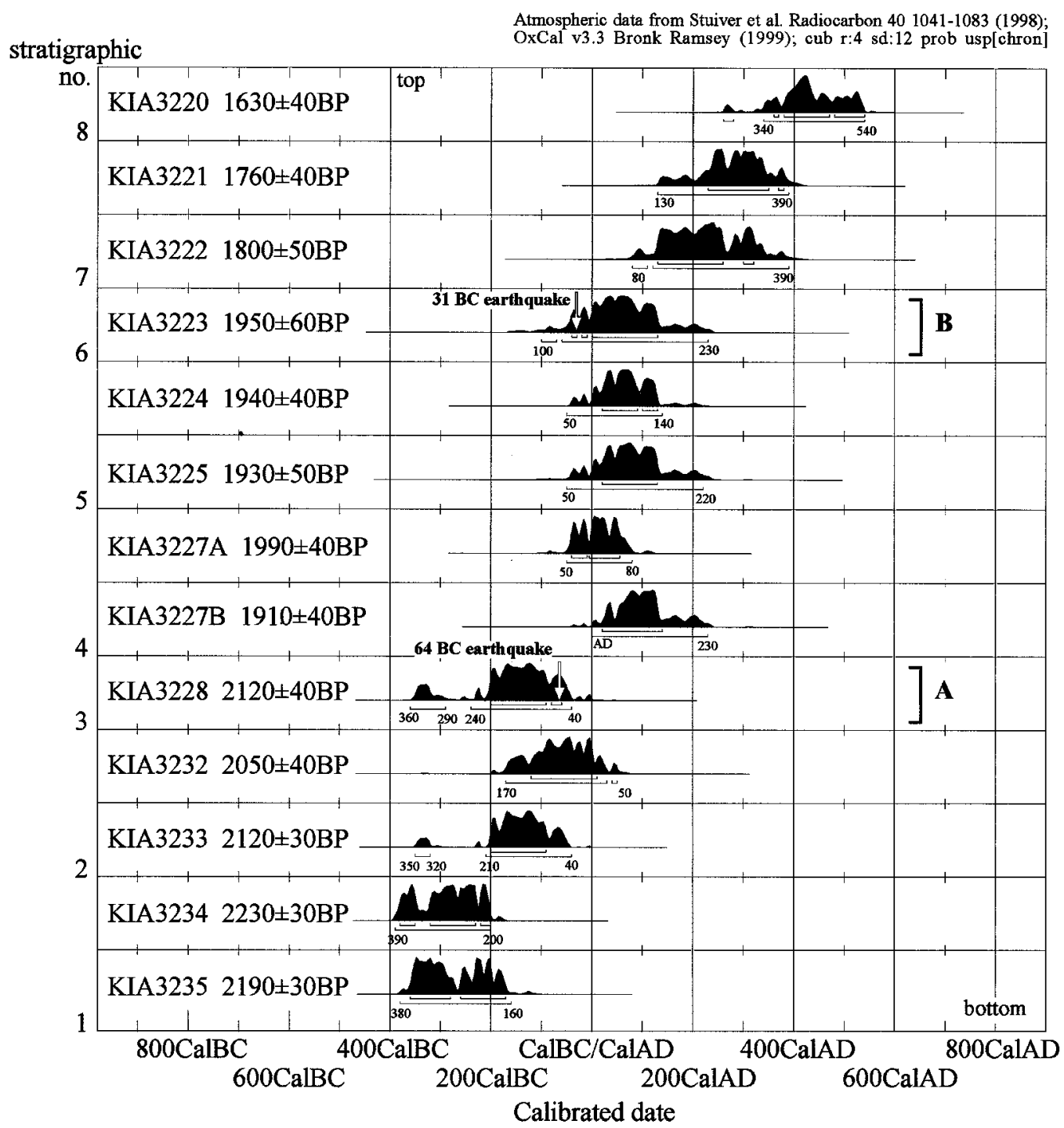

Figure 3a Calibrated date distribution for samples from the Ze'elim sequence (Tables 1 and 2). The samples are arranged in stratigraphic order from bottom to top. Samples collected from the seismite record are marked in capital letters (A-H). Correlated earthquakes are marked with arrows. The calibrated ranges of the samples collected from seismites $\mathrm{E}$ and $\mathrm{F}$ are very similar but show differences in their distribution. The distribution of the older samples from seismite $\mathrm{E}$ is larger in the older part of the range (in gray and labeled II), while that of the younger samples from seismite F is shifted towards the younger range (labeled I). The difference in the distribution of the samples is in accordance with the stratigraphic order of the samples and supports the correlation of the 1212 and $1293 \mathrm{AD}$ earthquakes. 


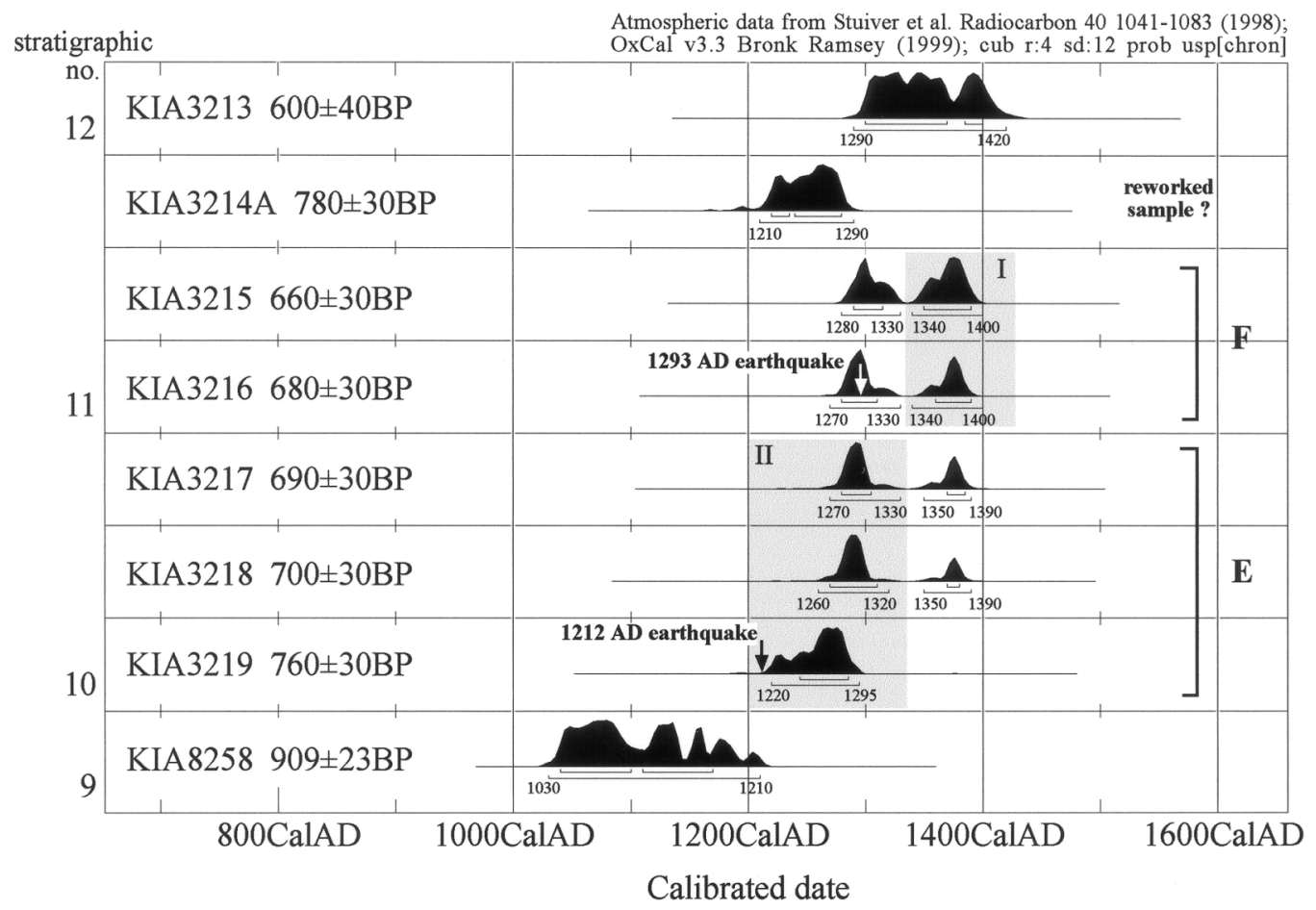

Figure 3b See Figure 3a

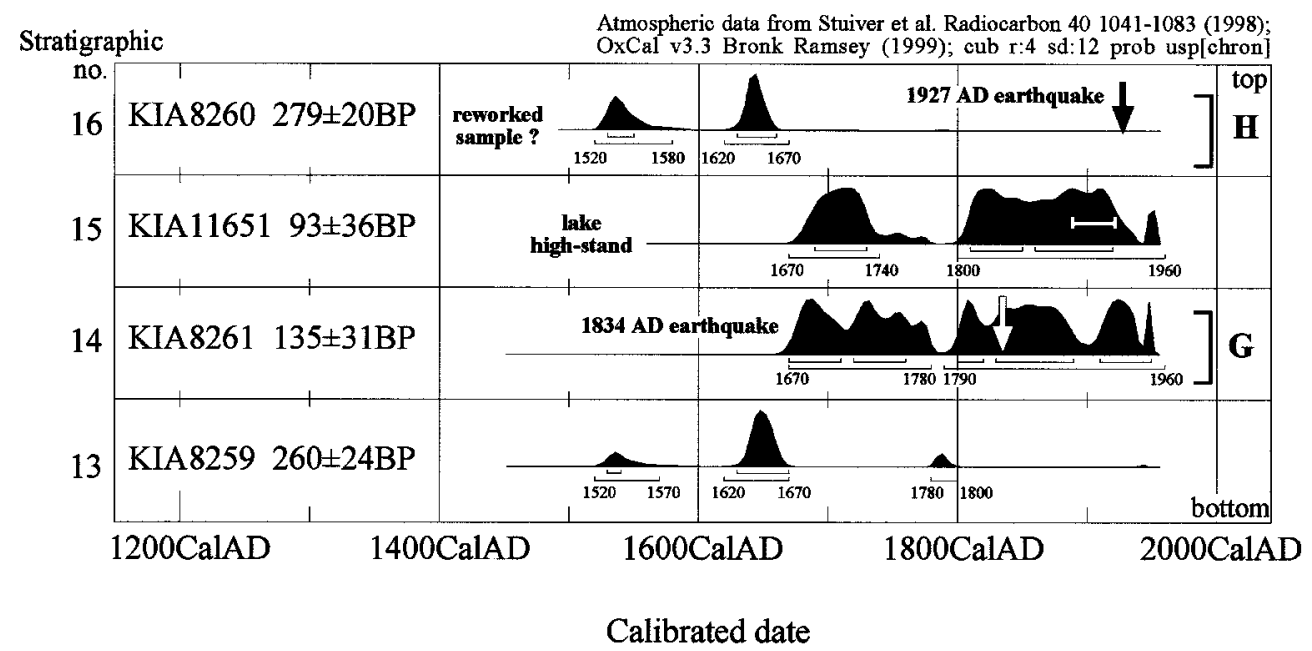

Figure 3c See Figure 3a 
Table 2 Chronology of the seismite record

\begin{tabular}{|c|c|c|c|c|c|}
\hline $\begin{array}{l}\text { Seismite } \\
\text { unit }^{\mathrm{a}}\end{array}$ & $\begin{array}{l}\text { Correlated } \\
\text { historic } \\
\text { earthquake }\end{array}$ & $\begin{array}{l}\text { Sample } \\
\text { lab nr } \\
\text { (KIA-) }\end{array}$ & $\begin{array}{l}\text { Calendar date in } 2 \sigma \text { error } \\
\text { ( } 95.4 \% \text { confidence) } \\
\text { and probability }\end{array}$ & $\begin{array}{l}\text { Reduced } \\
\text { calibrated ages of } \\
\text { the seismite unit }{ }^{b}\end{array}$ & $\begin{array}{l}\text { Calendar date } \\
\text { in } 1 \sigma \text { error } \\
(68.2 \% \text { confidence })\end{array}$ \\
\hline A & $64 \mathrm{BC}$ & 3228 & $\begin{array}{l}360-290 \text { BC }(9.5 \%) \\
240-40 \text { BC }(85.9 \%)\end{array}$ & $200-64 \mathrm{BC}$ & $\begin{array}{l}200-90 \mathrm{BC} \\
80-60 \mathrm{BC}\end{array}$ \\
\hline B & $31 \mathrm{BC}$ & 3223 & $\begin{array}{l}100-70 \text { BC }(1.6 \%) \\
60 \text { BC-230 AD }(93.8 \%)\end{array}$ & $50 \mathrm{BC}-31 \mathrm{AD}$ & $\begin{array}{l}40-30 \mathrm{BC} \\
20-10 \mathrm{BC} \\
\mathrm{AD}-130 \mathrm{AD}\end{array}$ \\
\hline \multirow[t]{3}{*}{$\mathrm{E}$} & $1212 \mathrm{AD}$ & 3219 & $1220-1295$ AD (95.4\%) & \multirow{3}{*}{$\begin{array}{l}\text { The correlated } \\
\text { earthquake is out } \\
\text { of the calibrated } \\
\text { range (see text) }\end{array}$} & $1244-1285$ AD \\
\hline & & 3218 & $\begin{array}{l}1260-1320(71.6 \%) \\
1350-1390(23.8)\end{array}$ & & $\begin{array}{l}1270-1310 \text { AD } \\
1370-1380 \text { AD }\end{array}$ \\
\hline & & 3217 & $\begin{array}{l}1270-1330(61.6 \%) \\
1350-1390(33.8 \%)\end{array}$ & & $\begin{array}{l}1280-1305 \text { AD } \\
1370-1385 \text { AD }\end{array}$ \\
\hline \multirow[t]{2}{*}{$\mathrm{F}$} & $1293 \mathrm{AD}$ & 3216 & $\begin{array}{l}1270-1330 \text { AD }(52.7 \%) \\
1340-1400 \text { AD }(42.7 \%)\end{array}$ & \multirow{2}{*}{$1270-1293 \mathrm{AD}$} & $\begin{array}{l}1280-1310 \text { AD } \\
1360-1390 \text { AD }\end{array}$ \\
\hline & & 3215 & $\begin{array}{l}1280-1330 \text { AD }(41.3 \%) \\
1340-1400 \text { AD }(54.1 \%)\end{array}$ & & $\begin{array}{l}1290-1315 \text { AD } \\
1350-1390 \text { AD }\end{array}$ \\
\hline G & $1834 \mathrm{AD}$ & 8261 & $\begin{array}{l}1670-1780 \text { AD }(41.1 \%) \\
1790-1960 \text { AD }(54.3 \%)\end{array}$ & 1670-1834 AD & $\begin{array}{l}1670-1710 \text { AD } \\
1720-1760 \text { AD } \\
1800-1820 \text { AD } \\
1830-1890 \text { AD } \\
1910-1950 \text { AD }\end{array}$ \\
\hline $\mathrm{H}$ & $1927 \mathrm{AD}$ & 8260 & $\begin{array}{l}1520-1580 \text { AD }(43.5 \%) \\
1620-1670 \text { AD }(51.9 \%)\end{array}$ & $\begin{array}{l}\text { Reworked sam- } \\
\text { ple, out of strati- } \\
\text { graphic order. }\end{array}$ & $\begin{array}{l}1530-1550 \mathrm{AD} \\
1630-1660 \mathrm{AD}\end{array}$ \\
\hline
\end{tabular}

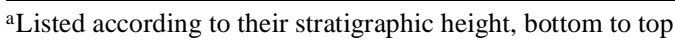

${ }^{\text {b}}$ Reduced calibrated ranges after applying the superposition principle on the samples' calendar ranges and correlation to a historically dated earthquake

\section{Correlation with Historic Earthquakes}

The Dead Sea area has been affected by seismic activity throughout historical time. Reported damages to nearby sites have been used to produce a historical record of the last four thousand years (Ambraseys et al. 1994; Amiran et al. 1994; Ben-Menahem 1991), representing one of the longest earthquake records on earth. Ken-Tor et al. (2001) demonstrated that all the seismites observed in the Ze'elim sequence correlate with historical earthquakes reported in catalogues. This correlation reduces the younger limit of the range of calibrated ${ }^{14} \mathrm{C}$ ages that date the seismites. The ${ }^{14} \mathrm{C}$ age of the sample collected from the seismite cannot be older than the known year of the earthquake that created the seismite (Figures $4 \mathrm{a}-\mathrm{e})$. In the following sections we present the ${ }^{14} \mathrm{C}$ data $(2 \sigma$ calibrated range) from the seismites labeled $\mathrm{A}-\mathrm{H}$ (excluding $\mathrm{C}$ and $\mathrm{D}$, which were dated by extrapolating sedimentation rates between ${ }^{14} \mathrm{C}$ dates) (Ken-Tor et al. 2001), their correlation with historic documented earthquakes, and discuss the implications of this procedure for the calibrated calendar ranges:

Seismite A. The lowest disturbed unit in the sequence. It was dated to $2120 \pm 40 \mathrm{BP}$ based on the age of sample KIA-3228, which was collected at of $73.5 \mathrm{~cm}$ above the base of the sequence. The $2 \sigma$ calibrated ranges are 360-290 BC and 240-40 BC (Table 2, Figure 3a). Two samples from the sequence below this seismite, at $14.5 \mathrm{~cm}$, were dated to $2190 \pm 30$ and $2230 \pm 30 \mathrm{BP}$ (calendar ranges: $380-160$ BC, 390-200 BC). At $51 \mathrm{~cm}$, two other samples were dated to $2120 \pm 30$ and $2050 \pm 40 \mathrm{BP}$ (350- 
$40 \mathrm{BC}, 170 \mathrm{BC}-50 \mathrm{AD}$ ) (Table 1, Figure 3a). These stratigraphically lower ages constrain the timing of event A towards the younger calendar range of 200-40 BC. Seismite A was correlated to the 64 BC earthquake, which lies within the $1 \sigma$ error calibration range of the sample collected from it. Since the deposition of the sample cannot be younger than earthquake deformation, the calibrated range of sample KIA-3228 is further reduced to 200-64 BC (Figure 4a).

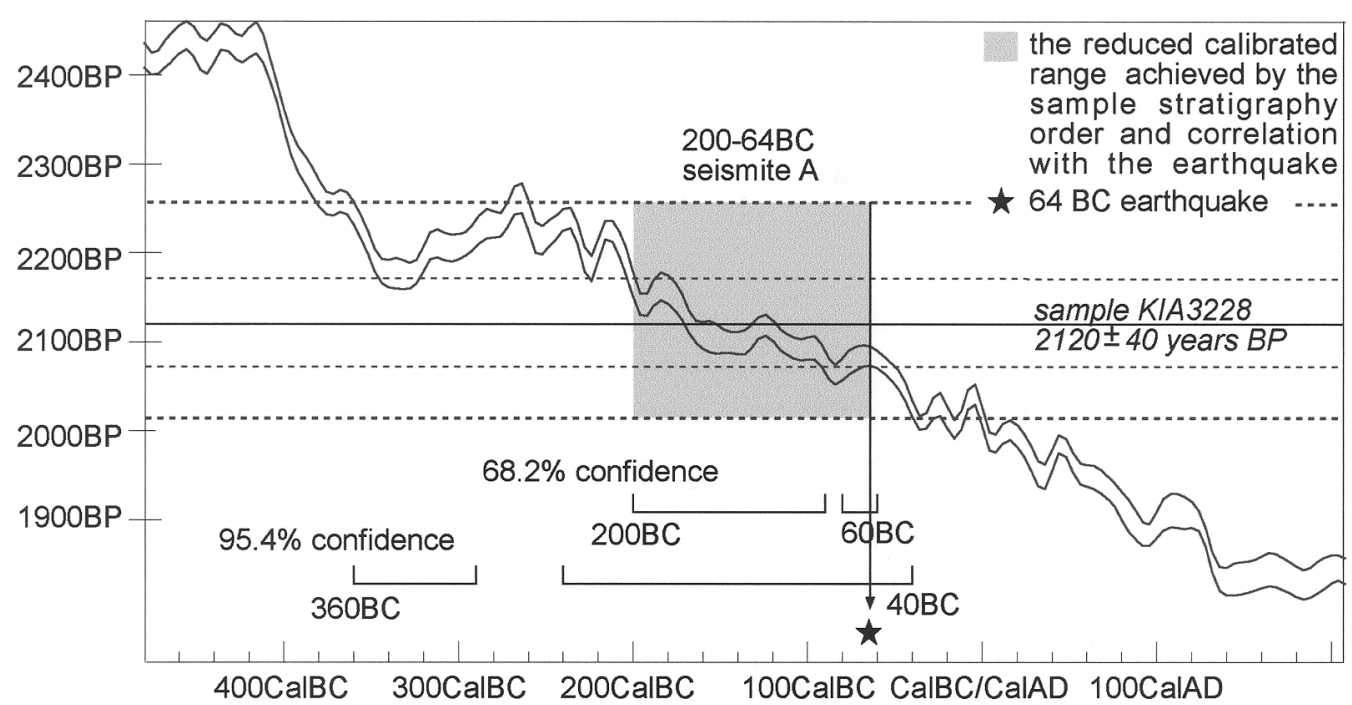

Figure 4a The calibration curve from Stuiver et al. (1998) and the intersection of the ${ }^{14} \mathrm{C}$ age of the samples collected from the seismites of the Ze' elim sequence. Thick dashed lines represent the $2 \sigma$ error ( $68.2 \%$ confidence) and fine dashed lines the $1 \sigma$ error ( $95.4 \%$ confidence). The uncertainty in the ages of samples collected from the seismites is reduced by overlapping calibrated ranges of stratigraphically lower samples and by correlating with historical earthquakes (in gray).

Seismite B. The time between events A and B was bracketed by four ${ }^{14} \mathrm{C}$ dates: $1910 \pm 40$ and 1990 $\pm 40 \mathrm{BP}(0-230 \mathrm{AD}, 50 \mathrm{BC}-80 \mathrm{AD})$ for samples at the height of $107 \mathrm{~cm}$, and $1930 \pm 50$ and 1940 $\pm 40 \mathrm{BP}(50 \mathrm{BC}-220 \mathrm{AD}, 50 \mathrm{BC}-140 \mathrm{AD})$ for samples at $132.5 \mathrm{~cm}$. Seismite B was dated to 1950 $\pm 60 \mathrm{BP}$ (KIA-3223) (100-70 BC and $60 \mathrm{BC}-230 \mathrm{AD}$ ) based on the age of a sample collected at $146 \mathrm{~cm}$ (Table 1, Figure 3a). The reduced calibrated range derived from the stratigraphic order of the samples is $50 \mathrm{BC}-230 \mathrm{AD}$. The association of the lower event $\mathrm{A}$ with the $64 \mathrm{BC}$ earthquake implies that event $\mathrm{B}$ is younger and therefore it can be correlated with an earthquake that occurred in the early spring of $31 \mathrm{BC}$. This earthquake falls in the $1 \sigma$ error range of sample KIA-3223 (Table 2). Since the sample date cannot be younger than the correlated earthquake, the correlation with the $31 \mathrm{BC}$ earthquake reduces the calibrated range of event B to 50-31 BC (Figure 4b).

Seismites $E$ and $F$. The timing of formation of seismite $\mathrm{E}$ is inferred from the ages of three samples (KIA-3219, KIA-3218, KIA-3217) as $760 \pm 30,700 \pm 30$ and $690 \pm 30$ BP (Tables 1 and 2) (combined calendar ranges of the samples: 1220-1330 AD and 1350-1390 AD; Figure 3b). Seismite F is dated by additional three samples (KIA-3216, KIA-3215, KIA-3214A) to $680 \pm 30,660 \pm 30$, and $780 \pm 30 \mathrm{BP}$ (Table 1) (1270-1330 AD and 1340-1400 AD; Figure 3b). Although remarkably very close in age, the $780 \pm 30 \mathrm{BP}$ age (from seismite F) is slightly out of stratigraphic order and probably represents reworked material. For the purpose of this study, it is excluded from the seismite age analysis. Statistically, the ${ }^{14} \mathrm{C}$ ages from Seismites $\mathrm{E}$ and $\mathrm{F}$ are almost indistinguishable. Nevertheless, the probability distribution of the ${ }^{14} \mathrm{C}$ ages and their stratigraphic order indicate two separate dates. 


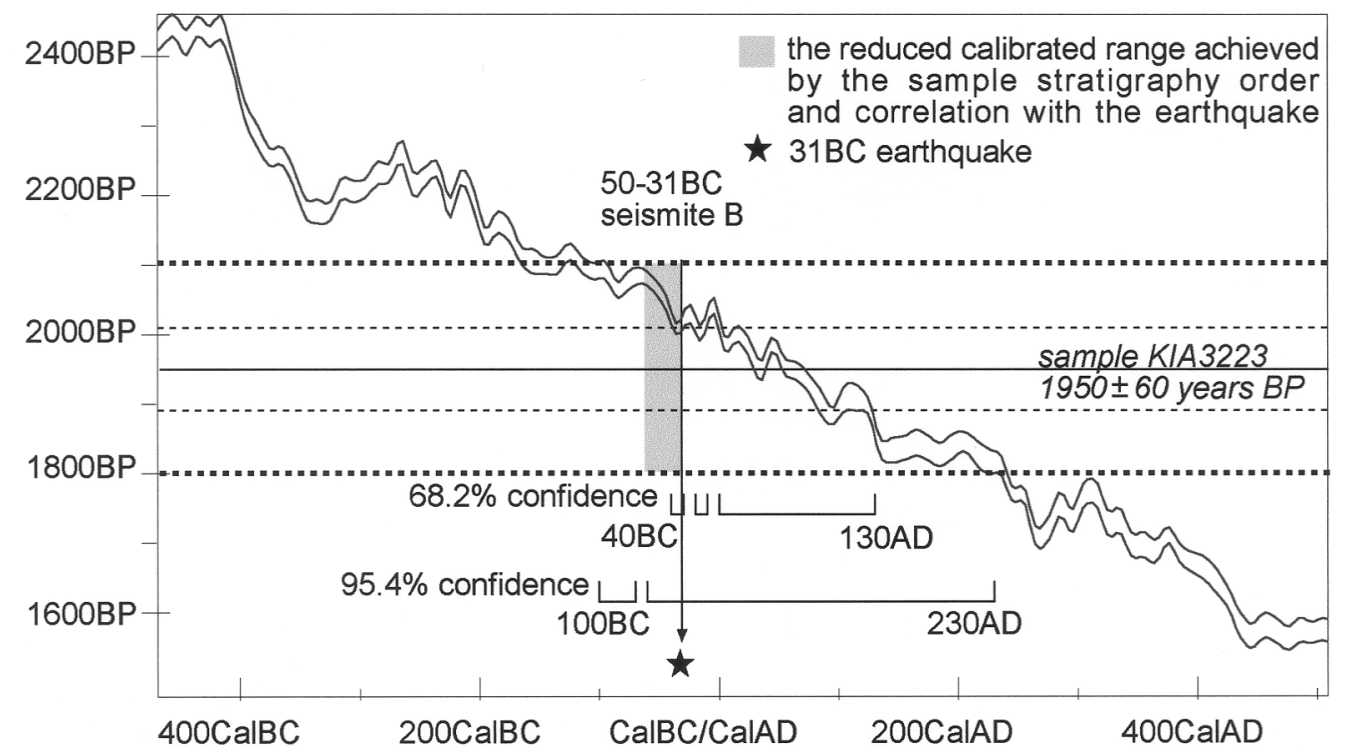

Figure $4 \mathrm{~b}$ See Figure $4 \mathrm{a}$

The samples from seismite E have higher distribution probability in the older range (II in Figure 3b), while the samples from seismite F are shifted towards the younger range (I in Figure $3 b$ ). This is consistent with the stratigraphic order of the samples, supporting the correlation with the historic earthquakes. Seismite $\mathrm{E}$ is possibly correlated to the $1212 \mathrm{AD}$ earthquake, only a few years separate the historic date and calendar range (Figure 4c, Table 2). Seismite F was correlated to the 1293 AD earthquake, which falls in its $1 \sigma$ error range. The correlation reduces the calendar range of seismite F to 1270-1293 AD (Figure 4d, Table 2).

Seismites $G$ and $H$. These were recorded as liquefied sand beds in the most recent part of the Ze'elim sequence. Seismites $\mathrm{G}$ and $\mathrm{H}$ are constrained by four ${ }^{14} \mathrm{C}$ ages described here in stratigraphic order (in BP): $260 \pm 24$ (KIA-8259) from the bottom of this sequence, $135 \pm 31$ (KIA-8261) collected from seismite G, $93 \pm 36$ (KIA-11651) from the topmost laminated lacustrine unit, and 279 \pm 20 (KIA-8260) from seismite $\mathrm{H}$.

The bottom sample is represented by three $2 \sigma$ calendar ranges: $1520-1570 \mathrm{AD}, 1620-1670 \mathrm{AD}$, and 1780-1800 AD. The sample from Seismite G corresponds to the calendar ranges of 1670-1780 AD and 1790-1960 AD. The sample from the laminated lacustrine unit represent the calendar ranges 1670-1740 AD and 1800-1960 AD. The stratigraphically youngest sample corresponds to an old calendar range of 1520-1580 AD and 1620-1670 AD (Tables 1,2, Figure 3c).

Limnologic and depositional evidence resolves the chronology and stratigraphy of this sequence. The liquefied layers $\mathrm{G}$ and $\mathrm{H}$ are separated by the laminated lacustrine unit (alternating aragonite and detritus), which marks a rise in the Dead Sea lake level at the end of the 19th century (Klein 1961). It appears that the first two samples from the bottom of the sequence are older than the 1890 AD lake level rise (Figure 3c). The age of the sample collected from the lacustrine unit must be limited to its younger calibrated range that fits the period of the lake rise. The upper sample in the sequence is stratigraphically younger but has an older ${ }^{14} \mathrm{C}$ age out of stratigraphic order, probably due to recy- 
cling. This interpretation allows the correlation of event $\mathrm{G}$ with the $1834 \mathrm{AD}$ earthquake before the high stand of the lake and event $\mathrm{H}$ with the $1927 \mathrm{AD}$ earthquake just following the high stand.

The $1834 \mathrm{AD}$ earthquake falls in the $1 \sigma$ calibration range of the sample collected from seismite $\mathrm{G}$. The correlation with the earthquake reduces the calibration range to 1670-1834 AD (Figure 4e). The disagreement between the age of the upper sample and the $1927 \mathrm{AD}$ event could reflect reworking of the organic debris, as it occurs in the recent shore environment of the Dead Sea when the lake level is declining. The difference between the age of the sample and the deformation of the unit by the 1927 earthquake reflects a possible long transport time (few centuries) of the sample along the shores or reworking of samples from newly exposed sediments.

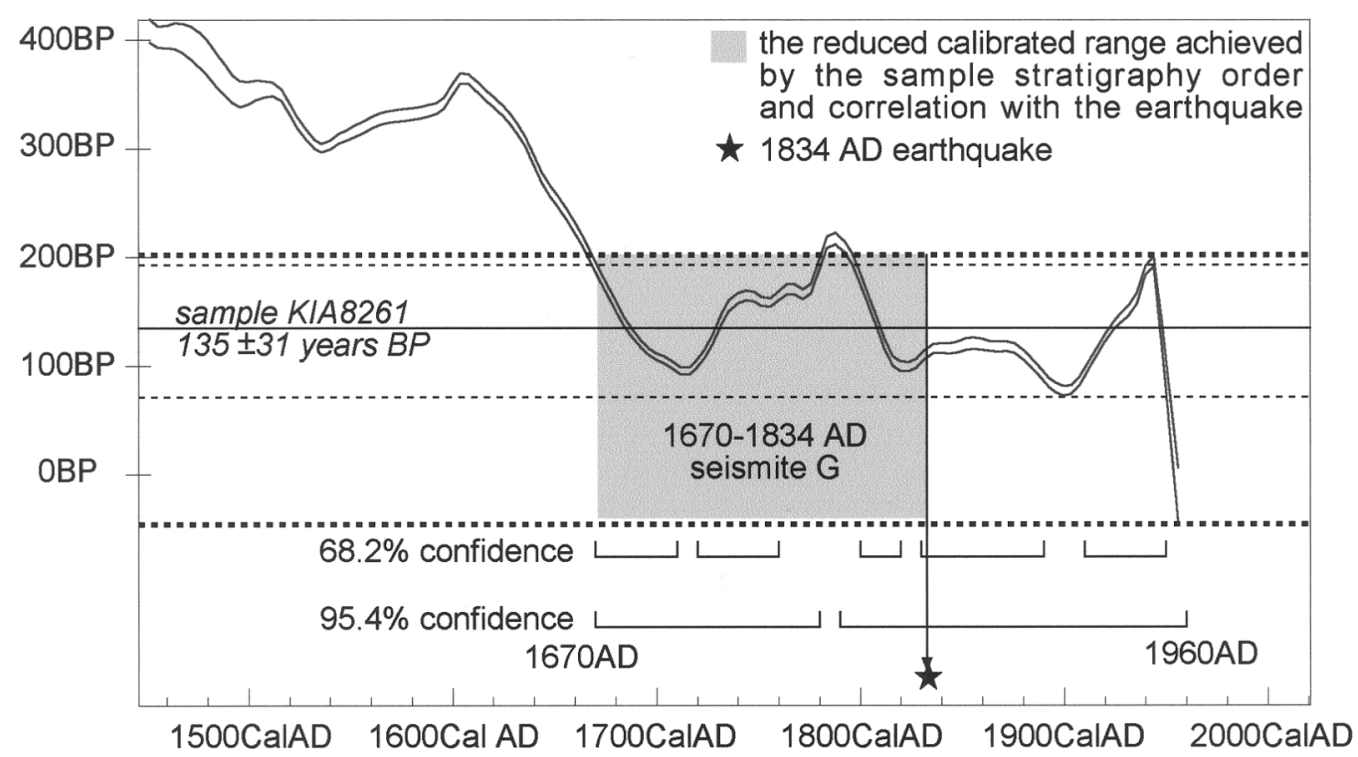

Figure 4e See Figure 4a

\section{DISCUSSION}

In this study the assessment of the precision of the calibrated ${ }^{14} \mathrm{C}$ data relies on three considerations: 1) statistical treatment of the ${ }^{14} \mathrm{C}$ data (the probability distribution of the measured data and calibration ranges); 2) limitation of the ${ }^{14} \mathrm{C}$ calibration ranges by stratigraphic considerations; and 3) correlation to known dates of seismic events. Thus, even in cases of small deviation from the historical earthquake date (e.g. the $1212 \mathrm{AD}$ event) the structure of our analysis appears to be robust.

The stratigraphic order of deposition and the correlation with historically dated earthquakes that were recorded in the Late Holocene sediments in the Dead Sea Basin were used to refine the ${ }^{14} \mathrm{C}$ dates of samples collected from the Ze'elim sequence (Ken-Tor et al. 2001). The comparison between the refined ${ }^{14} \mathrm{C}$ ages and the historic earthquake dates enables us to examine the accuracy of the ${ }^{14} \mathrm{C}$ date. The uncertainty in the ${ }^{14} \mathrm{C}$ age determination contains the systematic errors in the analytical and calibration procedures and the geological uncertainty, which reflects transportation and deposition processes. Both uncertainties are not uniform. 
The calibrated ranges of the samples collected from six seismites were reduced significantly by the use of overlapping stratigraphically older samples and the correlation with known historical earthquakes (Figure 4, Table 2). The refined ages are reduced by a few decades to more than two centuries. The uncertainty remaining for most cases (less than two decades) includes the maximum lag period of transport and deposition of the sample perior to the earthquake. The only ${ }^{14} \mathrm{C}$ sample that significantly predates the correlated earthquake (by stratigraphic considerations) was collected from a coarse sand unit, a typical shore environment deposition. The organic samples probably represent reworked material yielding ages a few centuries older than the earthquake. This single result must be supported by more ${ }^{14} \mathrm{C}$ dates, but our observation shows that samples collected from shore deposits can have a relatively long transport period.

\section{CONCLUSIONS}

1. The calibration ranges of ${ }^{14} \mathrm{C}$ ages of organic debris from earthquake-disturbed layers (seismites) in the Holocene sedimentary section at the Ze'elim Terrace (Dead Sea) were significantly reduced by (a) using the stratigraphic order of dated samples in the section, and (b) correlation to historically dated earthquakes.

2. The corresponding historic earthquake of most seismites lies within the $1 \sigma$ error envelope of the ${ }^{14} \mathrm{C}$-dated samples. In several cases the reduced calendar range is less than a few decades.

3. The reduced ranges represent the maximum possible lag period between the age of the sample collected from the seismite and the time of deformation (which constrains the upper limit of deposition). This is typically a few decades to less than two centuries for samples collected from lacustrine facies and probably a few centuries for samples collected from the shore facies.

4. The assessment of the ${ }^{14} \mathrm{C}$ ages of the Ze'elim sediments attests to the reliability of organic debris for ${ }^{14} \mathrm{C}$ dating of Holocene sediments in the Dead Sea area. It demonstrates our ability to achieve highly precise (within several decades) ${ }^{14} \mathrm{C}$ ages. This result may have implications for age determination of older pre-historical sequences in this and other arid regions.

\section{ACKNOWLEDGMENTS}

We wish to thank Nicolas Waldmann, Yuval Bartov, Claudia Migowski, and GSI technicians for their assistance in the fieldwork. This research was supported by the German-Israel Foundation for Research and Development (GIF grant \#137/95), the Israel-United States Bi-National Science Foundation (BSF grant \#97-00286), Israel Science Fund (ISF, Grant \# 694/95), the Dead Sea Minerva Center and the Ministry of National Infrastructure.

\section{REFERENCES}

Ambraseys NN, Melville CP, Adams RD 1994. The seismicity of Egypt, Arabia and the Red Sea: a historical review. Cambridge University Press.181 p.

Amiran DHK, Arieh E, Turcotte T. 1994. Earthquake in Israel and adjacent areas: macroseismic observation since 100 BCE. Israel Exploration Journal 44:260 305.

Ben-Menahem A. 1991. Four thousand years of seismicity along the Dead Sea Rift. Journal of Geophysical Research 96:195-216.

Bronk Ramsey C. 1999. OxCal program 3.3. Oxford Radiocarbon Accelerator Unit.

Enzel Y, Kadan G, Eyal Y. 2000. Holocene earthquakes in the Dead Sea graben from a fan-delta sequence.
Quaternary Research 53:34-48.

Garfunkel Z, Zak I, Freund R. 1981. Internal structure of the Dead Sea Leaky Transform (rift) in relation to plate kinematics. Tectonophysics 80:81-108.

Ken-Tor R, Agnon A, Enzel Y, Stein M, Marco S, Negendank JFW. 2001. High-resolution geological record of historic earthquakes in the Dead Sea basin. Journal of Geophysical Research 106: 2221-34.

Klein C. 1961. On the fluctuations of the level of the Dead Sea since the beginning of the 19th century. Hydrological Paper No. 7. Hydrological Service, Ministry of Agriculture, Jerusalem.

Marco S, Agnon A. 1995. Prehistoric earthquake deformations near Masada, Dead Sea graben. Geology 23: 
695-98.

Marco S, Stein M, Agnon A, Ron H. 1996. Long-term earthquake clustering: a 50,000-year paleoseismic record in the Dead Sea Graben. Journal of Geophysical Research 101:6179-91.

Suess HE. 1965. Secular variations of the cosmic-rayproduced carbon 14 in the atmosphere and their inter- pretations. Journal of Geophysical Research 70:593752.

Stuiver M, Reimer PJ, Bard E, Beck JW, Burr GS, Hughen KA, Kromer B, McCormac G, van der Plicht J, Spurk M. 1998. INTCAL98 radiocarbon age calibration, 24,000-0 cal BP. Radiocarbon 40(3):1041-83. 